\title{
PENGARUH PENERAPAN MODEL PEMBELAJARAN KOOPERATIF TIPE TEAMS GAMES TOURNAMENT (TGT) TERHADAP HASIL BELAJAR PESERTA DIDIK PADA MATA PELAJARAN EKONOMI DI MAN 2 KOTA TASIKMALAYA
}

\author{
Hernata Diana Tari', Utty Suwirta², Dedeh ${ }^{3}$ \\ 1,2,3 Program Studi Pendidikan Akuntansi, Universitas Galuh, Jl. R. E. Martadinata No.150, Ciamis, Indonesia \\ Email: hernatadiana88@gmail.com
}

\begin{abstract}
The low learning outcomes is a problem in the study, because learning outcomes are one of success indicators of learning process. Researchers assumes that the implementation of the cooperative model Times Games Tournament type affects the improvement of student learning outcomes. The formulation of the problem in this study are : 1). Is there an increase in learning outcomes of students who are taught by using the cooperative learning model of the thypes of Teams Games Tournament (TGT) in the initial measurement (pretest) and final measurement (posttest) ? 2). Whether or not there is an increase in learning outcomes of students who are taught by using the lecture method (konvensional) in the initial measurement (pretest) and final measurement (posttest) ? 3). Whether or not there are differences in learning outcomes of students who are taught ny using use the learning models Teams Games Tournament (TGT) with learning outcomes of student who are taught by using the lecture method (conventional) in the initial measurement (pretest) and final measurement (posttest) ? Thus, the purpose of this study is to 1). improve learning outcomes of the students who are taught by using the cooperative learning model of the types of Teams Games Tournament (TGT) in the initial measurement (pretest) and final measurement (posttest); 2). improve learning outcomes of the students who are taught by using the lecture method (conventional) in the initial measurement (pretest) and final measurement (posttest). 3). find out the differences in learning outcomes of students who are taught by using the models of Teams Games Tournament (TGT) learning with learning outcomes of students who are taught by using the lecture method (conventional) in the initial measurement (pretest) and final measurement (posttest). The research method used in this study is the Quasiexperimental design experimental method. Based on the results of the study, it shows that there are differences in student learning outcomes in economic subjects class X MIPA in MAN 2 Tasikmalaya City.
\end{abstract}

Keywords: Cooperative Learning Teams Games Tournament, Conventional Learning.

\begin{abstract}
ABSTRAK
Permasalahan yang diangkat dalam penelitian ini adalah rendahnya hasil belajar. Deperti kita ketahui, hasil belajar merupakan salah satu tolak ukur keberhasilan proses pembelajaran. Peneliti berasumsi bahwa dengan diterapkannya model pembelajaran Kooperatif tipe Times Games Tournament akan mempengaruhi peningkatan hasil belajar peserta didik. Rumusan masalah dalam penelitian ini yaitu: 1). Apakah terdapat peningkatan hasil belajar peserta didik yang menggunakan model pembelajaran kooperatif tipe Teams Games Tournament (TGT) pada pengukuran awal (pretest) dan pengukuran akhir (posttest) ? 2). Apakah terdapat peningkatan hasil belajar peserta didik yang menggunakan metode ceramah (konvensional) pada pengukuran awal (pretest) dan pengukuran akhir (posttest) ? 3). Apakah terdapat perbedaan hasil belajar peserta didik yang menggunakan model pembelajaran Teams Games Tournament (TGT) dengan hasil belajar peserta didik yang menggunakan metode ceramah (konvensional) pada pengukuran awal (pretest) dan pengukuran akhir (posttest) ?. Adapun tujuan penelitian ini yaitu: 1). Peningkatan hasil belajar peserta didik yang menggunakan model pembelajaran kooperatif tipe Teams Games Tournament (TGT) pada pengukuran awal (pretest) dan pengukuran akhir (posttest). 2). Peningkatan hasil belajar peserta didik yang menggunakan metode ceramah (konvensional) pada pengukuran awal (pretest) dan pengukuran akhir (posttest). 3). Perbedaan hasil belajar peserta didik yang menggunakan model pembelajaran Teams Games Tournament (TGT) dengan hasil belajar peserta didik yang menggunakan metode ceramah (konvensional) pada pengukuran awal (pretest) dan pengukuran akhir (posttest). Metode penelitian yang digunakan yaitu metode eksperimen tipe Quasi Eksperimen Design. Berdasarkan hasil penelitian menunjukkan bahwa terdapat perbedaan hasil belajar peserta didik pada mata pelajaran ekonomi kelas X MIPA di MAN 2 Kota Tasikmalaya.
\end{abstract}

Kata Kunci: Pembelajaran Kooperatif Teams Games Tournament, Pembelajaran Konvensional

Cara sitasi: Tari, H. D ., Suwirta, U \& Dedeh. (2020). Pengaruh Penerapan Model Pembelajaran Kooperatif Tipe Teams Games Tournament (TGT) terhadap Hasil Belajar Peserta Didik pada Mata Pelajaran Ekonomi di MAN 2 Kota Tasikmalaya. J-KIP (Jurnal Keguruan dan IImu Pendidikan) , 1 (2), 19-26. 


\section{PENDAHULUAN}

Hasil belajar merupakan gambaran tentang bagaimana peserta didik memahami materi yang disampaikan oleh pendidik. Hasil belajar merupakan output nilai yang berbentuk angka atau huruf yang didapat oleh peserta didik setelah menerima materi pembelajaran melalui sebuah tes atau ujian yang disampaikan oleh pendidik. Dalam hasil belajar tersebut pendidik dapat menerima informasi seberapa jauh peserta didik memahami materi yang dipelajari.

Keberhasilan peserta didik dalam mencapai hasil belajar pada setiap peserta didik berbedabeda. Faktor-faktor yang mempengaruhi keberhasilan peserta didik dalam mencapai hasil belajar dikelompokkan menjadi dua yaitu faktor internal dan faktor eksternal. Faktor internal adalah segala faktor yang berasal dari dalam diri peserta didik, diantaranya kepribadian, motivasi dan sebagainya. Sedangkan faktor eksternal adalah segala faktor yang berasal dari luar peserta didik, diantaranya lingkungan, keluarga, pergaulan, fasilitas belajar, dan sebagainya.

Belajar itu sendiri merupakan suatu proses dari seseorang yang berusaha memperoleh suatu bentuk perubahan perilaku yang relatif menetap. Dalam kegiatan pembelajaran atau kegiatan intruksional, biasanya pendidik menetapkan tujuan belajar. Peserta didik yang berhasil dalam belajar adalah yang berhasil mencapai tujuan-tujuan pembelajaran atau tujuan intruksional.

Menurut Bloom tiga ranah (domain) hasil belajar yaitu, kognitif, afektif dan psikomotorik. Adapun pendapat menurut Abdurrahman (1999) "Masukan dari sistem tersebut berupa macammacam informasi sedangkan keluarannya adalah perbuatan atau kinerja (peformance)".

Berdasarkan uraian tersebut dapat diketahui bahwa hasil belajar adalah pencapaian bentuk perubahan perilaku yang cenderung menetap dari ranah kognitif, afektif, dan psikomotoris dari proses belajar yang dilakukan dalam waktu tertentu. Untuk memperoleh hasil belajar, dilakukan evaluasi atau penilaian yang merupakan tindak lanjut atau cara mengukur tingkat penguasaan peserta didik. Kemajuan prestasi belajar peserta didik tidak saja diukur dari tingkat penguasaan ilmu pengetahuan tetapi juga sikap dan keterampilan. Dengan demikian penilaian hasil belajar peserta didik mencakup segala hal yang dipelajari di sekolah, baik itu menyangkut pengetahuan, sikap dan keterampilan.

Proses penilaian terhadap hasil belajar dapat memberikan informasi kepada pendidik tentang kemajuan peserta didik, tetapi hingga saat ini mutu pendidikan masih jauh dari apa yang diharapkan, masih banyak peserta didik khususnya pada mata pelajaran ekonomi hasil belajarnya masih dibawah rata-rata Kriteria Ketuntasan Minimal (KKM). Berdasarkan pengamatan ternyata peserta didik kurang aktif dan kurang bekerja sama dengan peserta didik yang lain dalam mengikuti kegiatan pembelajaran, itu merupakan masalah yang perlu dicari solusinya. Hal ini dipengaruhi oleh pembelajaran yang berlangsung selama ini masih berpusat pada pendidik (teacher center) dan kurangnya variasi dalam pembelajaran, sehingga menjadikan peserta didik bosan dan pasif dalam berinteraksi untuk mendapatkan pengetahuannya. Seperti halnya peserta didik kurang sekali mendapat kesempatan untuk menyatakan pendapat, serta peserta didik hampir tidak pernah dituntut untuk mencoba strategi dan cara (alternatif) sendiri dalam memecahkan masalah.

Berdasarkan observasi hasil belajar peserta didik Nilai Ulangan Akhir Semester dan wawancara kepada guru ekonomi di MAN 2 KOTA TASIMALAYA, timbul masalah dalam kegiatan belajar mengajar di kelas. Hal tersebut dapat diketahui berdasarkan hasil belajar Ulangan Akhir Semester mata pelajaran Ekonomi. Untuk lebih jelasnya mengenai nilai peserta didik dapat dilihat pada Tabel 1 yang merupakan nilai Ulangan Akhir Semester. 
Tabel 1. Nilai Ulangan Akhir Semester 1

\begin{tabular}{cccccccc}
\hline Kelas & $\begin{array}{c}\text { Jumlah } \\
\text { Peserta } \\
\text { Didik }\end{array}$ & KKM & $\begin{array}{c}\text { Nilai } \\
\text { Tertinggi }\end{array}$ & $\begin{array}{c}\text { Nilai } \\
\text { Terendah }\end{array}$ & $\begin{array}{c}\text { Nilai } \\
\text { Dibawah } \\
\text { KKM }\end{array}$ & $\begin{array}{c}\text { Diatas } \\
\text { KKM }\end{array}$ & $\begin{array}{c}\text { Nilai } \\
\text { Rata-rata }\end{array}$ \\
\hline X.MIPA 1 & 38 & 65 & 82 & 60 & 23 Orang & 15 Orang & 64,13 \\
X.MIPA 2 & 38 & 65 & 85 & 60 & 27 Orang & 12 Orang & 63,61 \\
X.MIPA 3 & 35 & 65 & 72 & 60 & 19 Orang & 16 Orang & 66,20 \\
\hline
\end{tabular}

Sumber : MAN 2 KOTA TASIKMALAYA (2019)

Berdasarkan Tabel 1. dapat dilihat bahwa nilai Ulangan Akhir Semester masih ada beberapa peserta didik yang belum memenuhi Kriteria Ketuntasan Minimal (KKM), yaitu 65,00. Kemudian jumlah peserta didik kelas X MIPA MAN 2 Kota Tasikmalaya ada 111 Orang, kelas X.MIPA 1 ada 38 orang dan X.MIPA 2 ada 38 orang, sedangkan kelas X.MIPA 3 ada 35 orang. Peserta didik yang nilainya diatas KKM ada 43 orang. Peserta didik yang nilainya dibawah KKM ada 68 orang.

Peserta didik kelas X MIPA MAN 2 Kota Tasikmalaya lebih banyak yang nilai UASnya dibawah KKM. Hal tersebut bisa disebabkan oleh beberapa faktor, baik faktor internal maupun eksternal. Dari wawancara yang dilakukan dengan guru mata pelajaran, salah satu faktor yang menyebabkan nilai peserta didik kurang dari KKM karena peserta didik kurang aktif dan kurang bekerjasama dengan peserta didik yang lain dalam pembelajaran, sehingga membuat peserta didik menjadi kaku dan kurang memotivasi dalam menyampaikan pendapat, serta pembelajaran maih berpusat pada pendidik (teacher center). Berkenaan dengan permasalahan yang telah diuraikan maka diperlukan solusi atau pemecahan masalah dalam mengoptimalkan proses pembelajaran. Pendidik memilih model yang tepat dengan materi pembelajaran, tujuan pembelajaran, kemampuan dasar peserta didik supaya memberikan pemahaman materi kepada peserta didik, oleh karena itu pendidik harus mampu menyiasati tipe-tipe atau model-model apa saja yang cocok digunakan oleh seorang pendidik pada saat proses pembelajaran. Salah satunya menggunakan model pembelajaraan kooperatif tipe Teams Games Tournament (TGT) dengan menggunakan model tersebut diharapkan peserta didik akan ikut serta dalam proses pembelajaran dan membuat peserta didik menjadi lebih aktif dan terdorong untuk bekerjasama dengan peserta didik lainnya dalam bertanya dan menyampaikan pendapat.

Penulis bermaksud menggunakan model pembelajaran kooperatif tipe Teams Games Tournament (TGT) untuk meneliti apakah ada perubahan apabila proses pembelajaran menggunakan model pembelajaran TGT (Teams Games Tournament) yang bertujuan untuk menuntut peserta didik agar lebih aktif dan terdorong untuk bekerjasama dengan peserta didik yang lain sehingga akan menigkatkan pada hasil belajar peserta didik. TGT (Teams Games Tournament) adalah salah satu tipe pembelajaran kooperatif yang menempatkan siswa dalam kelompok-kelompok belajar yang beranggotakan 5 sampai 6 orang siswa yang memiliki kemampuan, jenis kelamin, dan suku kata atau ras yang berbeda.

Menurut Saco (Rusman, 2012), dalam TGT siswa memainkan permainan dengan anggotaangggota tim mereka masing-masing. Permainan dapat disusun guru dalam bentuk kuis berupa pertanyaan-pertanyaan yang berkaitan dengan materi pelajaran. Kadang-kadang dapat juga diselingi dengan pertanyaan yang berkaitan dengan kelompok (identitas mereka). Menurut Slavin pembelajaran kooperatif tipe TGT terdiri dari lima langkah tahapan yaitu tahap penyajian kelas (class precentation), belajar dalam kelompok (teams), permainan (games), pertandingan (tournament), dan penghargaan kelompok (team recognition).

Berdasarkan uraian yang telah disampaikan maka tujuan penelitian ini adalah untuk mengetahui: a) Perbedaan hasil belajar peserta didik yang menggunakan model pembelajaran kooperatif tipe Teams Games Tournament (TGT) pada pengukuran awal (pretest) dan pengukuran akhir (posttest) di kelas X MIPA MAN 2 Kota Tasikmalaya; b) Perbedaan hasil belajar peserta didik yang menggunakan model pembelajaran kooperatif tipe Teams Games Tournament (TGT) dengan 
metode ceramah (konvensional) pada pengukuran akhir (posttest) di kelas X MIPA MAN 2 Kota Tasikmalaya.

\section{METODE PENELITIAN}

Metode yang dipergunakan dalam penelitian ini metode penelitian eksperimen. (Moh, 2013) menyatakan bahwa "eksperimen adalah observasi di bawah kondisi buatan (artifical condition) dimana kondisi tersebut dibuat dan diatur oleh si peneliti". Dengan demikian, penelitian eksperimental adalah penelitian yang dilakukan dengan mengadakan manipulasi terhadap objek penelitian serta adanya kontrol.

Bentuk eksperimen yang akan digunakan adalah Quast Experimental Design dengan Nonequivalent Control Group Design. Dalam penelitian ini ada dua kelompok sampel yaitu kelompok eksperimen dan kelompok kontrol (kelompok banding). Desain Eksperimen dapat digambarkan sebagai berikut:

\section{Tabel 2. Desain Penelitian nonequivalent Control Group Design}

\begin{tabular}{lccc}
\hline \multicolumn{1}{c}{ Kelas } & Pretes & Treatment & Posttest \\
\hline Eksperimen & $\mathrm{O}_{1}$ & $\mathrm{X}$ & $\mathrm{O}_{2}$ \\
Kontrol & $\mathrm{O}_{3}$ & & $\mathrm{O}_{4}$ \\
\hline
\end{tabular}

(Sugiyono, 2017)

Keterangan:

$\mathrm{O}_{1} \quad$ : Pretest kelas eksperimen

$\mathrm{O}_{2} \quad$ : Posttest kelas eksperimen

$\mathrm{O}_{3} \quad$ : Pretest kelas kontrol

$\mathrm{O}_{4} \quad$ : Posttest kelas kontrol

$\mathrm{X} \quad$ : Treatment dengan menggunakan model kooperatif tipe Teams Games Tournament (TGT).

Populasi dalam penelitian ini adalah peserta didik kelas XMIPA MAN 2 Kota Tasikmalaya Tahun Ajaran 2018/2019 yang berjumlah 111 orang peserta didik. Dalam penelitian ini kegiatan pemilihan sampel menggunakan teknik sampling purposive, sehingga peneliti memilih sampel dengan pertimbangan tertentu. Hasilnya peneliti memilih kelas X MIPA 2 sebagai kelas eksperimen dan kelas X MIPA 1 sebagai kelas kontrol. Untuk membuktikan kelas X MIPA 1 dan 2 layak dijadikan sampel maka dilakukan uji homogenitas

Data penelitian dikumpulkan dengan cara memberikan tes awal dan tes akhir, dimana tes awal dilakukan sebelum pengajaran dimulai yang bertujuan untuk mengetahui kemampuan awal siswa terhadap pelajaran yang belum mereka kuasai, sedangkan tes akhir dilakukan pada akhir proses pembelajaran yang bertujuan untuk mengetahui pencapaian siswa terhadap materi pembelajaran yang sudah disampaikan.

Data hasil penelitian ini, yaitu hasil belajar siswa yang dihitung menggunakan uji t, dengan tujuan untuk mengetahui Peningkatan hasil belajar peserta didik menggunakan Teams Games Tournment (TGT) pada pengukuran awal (Pretest) dan pengukuran akhir (Posttest) di kelas X MAN 2 Kota Tasikmalaya pada pengukuran awal dan pengukuran akhir dan untuk mengetahui perbedaan hasil belajar antara peserta didik menggunakan metode pembelajaran inkuiri dibandingkan dengan peserta didik yang menggunakan metode pembelajaran konvensional pada pengukuran akhir (Posttest) di kelas X MAN 2 Kota Tasikmalaya. 


\section{HASIL DAN PEMBAHASAN}

Agar dapat mengetahui peningkatan hasil belajar peserta didik yang menggunakan model pembelajaran Teams Games Toumament (TGT) pada mata pelajaran Ekonomi kompetensi dasar Perkoperasian dalam Perekonomian Indonesia pada pengukuran awal (pretest) dan pada pengukuran akhir (posttest). Data hasil belajar peserta didik pada pengukuran tes awal (pretest) di kelas eksperimen (X MIPA 2) dengan jumlah sampel sebanyak 38 siswa, nilai tertinggi sebesar 75 dan nilai terendah 37,5 . Untuk nilai rata-rata diperoleh sebesar 61,68 dan modus (nilai yang paling sering muncul) adalah nilai 62,5. Setelah diberi perlakuan menggunakan model pembelajaran model pembelajaran Teams Games Tournament (TGT) dengan jumlah sampel sebanyak 38 peserta didik, diperoleh nilai tertinggi sebesar 93,75 dan nilai terendah sebesar 68,75 . Nilai rata-rata sebesar 82,57 dan modus (nilai yang paling sering muncul) adalah nilai 81,25.

Berdasarkan perhitungan N-Gain dari 38 peserta didik kelas X MIPA 2 MAN 2 Kota Tasikmalaya sebagai kelas eksperimen yang mendapatkan perlakuan menggunakan model pembelajaran Teams Games Tournament (TGT) diperoleh 5 peserta didik mempunyai kategori tinggi dan 33 peserta didik mempunyai kategori sedang. Berdasarkan hasil penelitian diketahui bahwa peningkatan hasil belajar peserta didik mata pelajaran Ekonomi kompetensi dasar Perkoperasian dalam Perekonomian Indonesia yang meggunakan model pembelajaran Teams Games Tournament (TGT) termasuk kedalam kategori sedang dengan N-Gain rata-rata 0,55 berada pada interval $(0,30<$ $\mathrm{N}-$ Gain $\leq 0,70$. Untuk mengetahui peningkatan hasil belajar peserta didik yang menggunakan model pembelajaran konvensional (kelas kontrol) pada mata pelajaran Ekonomi kompetensi dasar Perkoperasian dalam Perekonomian Indonesia pada pengukuran akhir (posttest).

Data hasil belajar peserta didik pada pengukuran tes awal (pretest) di kelas kontrol (X MIPA 1) dengan jumlah sampel sebanyak 38 peserta didik, nilai tertinggi sebesar 81,25 dan nilai terendah 43,75. Untuk nilai rata-rata diperoleh sebesar 62,83 dan modus (nilai yang paling sering muncul) adalah nilai 68,75 . Setelah diberi perlakuan menggunakan model pembelajaran model pembelajaran konvensional dengan jumlah sampel sebanyak 38 peserta didik, diperoleh nilai tertinggi sebesar 81,25 dan nilai terendah sebesar 68,75 . Nilai rata-rata sebesar 75,16 dan modus (nilai yang paling sering muncul) adalah nilai 68,75 .

Hasil gambaran subjek yang ada maka ditentukan nilai N-Gain pada kelas kontrol berdasarkan rata-rata skor pretest dan posttest, tingkat pengukuran awal (pretest) peserta didik yaitu dengan rata-rata sebesar 62,83 sedangkan tingkat pengukuran akhir (posttest) peserta didik yaitu rata-ratanya sebesar 75,16 hal ini menunjukkan adanya peningkatan hasil belajar. Dari 38 peserta didik kelas X MIPA 1 MAN 2 Kota Tasikmalaya sebagai kelas kontrol yang mendapatkan perlakuan menggunakan model pembelajaran Konvensional diperoleh 22 peserta didik mempunyai kategori sedang dan 16 peserta didik mempunyai kategori rendah. Berdasarkan hasil penelitian diketahui bahwa peningkatan hasil belajar peserta didik mata pelajaran Ekonomi kompetensi dasar Perkoperasian dalam Perekonomian Indonesia yang meggunakan model pembelajaran Konvensional termasuk kedalam kategori sedang dengan $\mathrm{N}$-Gain rata-rata 0,33 berada pada interval $(0,30<\mathrm{N}$-Gain $\leq 0,70)$.

Penelitian yang telah dilakukan oleh peneliti dapat membuktikan bahwa penggunaan model Teams Games Tournament (TGT) dengan menggunakan model konvensional berpengaruh terhadap hasil belajar peserta didik. Dengan hasil belajar peserta didik kelas eksperimen dan kelas kontrol pada pengukuran awal (pretest) dan pengukuran akhir (posttest) yang dihitung dengan menggunakan rumus N-Gain, dimana hasil untuk kelas eksperimen berada pada kategori sedang $(0,55)$ dengan ratarata nilai 82,57 dan untuk kelas kontrolpun berada pada kategori sedang $(0,33)$ dengan rata-rata nilai 75,16. Hal ini membuktikan bahwa dalam penggunaan model Teams Games Tournament (TGT) dengan metode pembelajaran konvensional tentu mempunyai perbedaan dalam hasil belajar peserta didik. Hal ini terjadi karena tingkat pemahaman dari masing-masing peserta didik berbeda, kemudian 
juga didasari dari proses belajar yang berbeda pula. Pada kelas eksperimen (X MIPA 2) peserta didik harus menguasai materi atau kisi-kisi yang telah dijelaskan dan dalam proses pembelajaran peserta didik dibagi menjadi 6 kelompok, pembagian kelompok dilihat dari nilai UAS tahun sebelumnya, kelompok tersebut 2 diantaranya kelompok nilai terendah $(<50)$ dan 4 kelompok lainnya adalah kelompok yang memiliki nilai tinggi ( $>50)$. Setelah dibagi menjadi beberapa kelompok, dipilih ketuanya dalam tiap-tiap kelompok, dimana tugas ketua tersebut adalah untuk perwakilan membawa soal yang telah diacak serta menjawab soal tersebut yang sebelumnya telah dirundingkan dengan teman sekelompoknya.

Dalam model pembelajaran ini, terdapat permainan dan perlombaan, juga pendidik yang memberikan reward atau penghargaan berupa hadiah yang membangkitkan semangat para peserta didik, sehingga peserta didik yang tadinya kurang aktif dalam model pembelajaran ini menjadi dituntut berpern aktif dalam kegiatan proses pembelajaran serta memahami pelajaran dengan cepat.

Sedangkan pada kelas kontrol (X MIPA 1) dengan metode pembelajaran konvensional lebih berpusat pada pendidik sehingga peserta didik cenderung pasif, dan kurang memperhatikan apa yang disampaikan oleh pendidik. Pembelajaran terkesan monoton, peserta didik kurang bersemangat dalam belajar karena metode konvensional ini tidak menuntut peserta didik untuk aktif, sehingga membuat peserta didik merasa ngantuk, bosan dan kebanyakan mengobrol dengan teman sebangku didalam kelas yang membuat peserta didik tidak berkonsentrasi terhadap apa yang disampaikan oleh pendidik. Dan akibat dari itu hasil belajar peserta didik kurang maksimal.

Metode pembelajaran merupakan salah satu hal penting dalam kegiatan belajar mengajar, maka dari itu sebelum memberikan pengajaran, seorang pendidik perlu mempertimbangkan model pembelajaran yang akan digunakan dalam proses pembelajaran yang sesuai dengan kompetensi yang dimiliki peserta didik. Sehingga pendidik akan mampu mencapai tujuan pembelajaran. Hal tersebut sejalan dengan Uno \& Mohamad (Lutvaidah, 2015) mengemukakan metode pembelajaran didefinisikan sebagai cara yang digunakan guru dalam menjalankan fungsinya dan merupakan alat untuk mencapai tujuan pembelajaran. Dengan demikian model Teams Games Tournament (TGT) memiliki peran yang positif dalam meningkatkan hasil belajar peserta didik, sehingga hasil belajar yang diperoleh menggunakan model Teams Games Tournament (TGT) lebih tinggi dibanding dengan menggunakan model konvensional (ceramah dan diskusi).

\section{KESIMPULAN}

Berdasarkan hasil penelitian dan pembahasan yang peneliti sajikan, maka dapat disimpulkan bahwa: 1) Terdapat peningkatan hasil belajar peserta didik yang menggunakan model pembelajaran Teams Games Tournament (TGT) berdasarkan rata-rata pada pengukuran awal (Pretest) dan pengukuran akhir (Posttest) di kelas eksperimen dengan kategori sedang. 2) Terdapat peningkatan hasil belajar peserta didik yang menggunakan model pembelajaran konvensional berdasarkan hasil rata-rata pada pengukuran awal (pretest) dan pengukuran akhir (posttest) di kontrol dengan kategori sedang. 3) Terdapat perbedaan hasil belajar peserta didik yang menggunakan model Teams Games Tournament (TGT) dan metode konvensional berdasarkan hasil rata-rata pada pengukuran akhir (posttest) dikelas eksperimen dan kelas kontrol dengan hasil akhir rata-rata di kelas eksperimen 82,57, dan dikelas kontrol 75,16.

\section{REKOMENDASI}

Sebaiknya penelitian menggunakan model Teams Games Tournament (TGT) memperhatikan juga dari sisi materi penelitian agar model pembelajaran tersebut tepat digunakan.

\section{UCAPAN TERIMAKASIH}

Ucapan terima kasih disampaikan untuk guru mata pelajaran ekonomi kelas X MIPA di MAN 2 Kota Tasikmalaya yang telah mengizinkan penelitian ini dilaksanakan. 


\section{DAFTAR PUSTAKA}

Abdurrahman, M. (1999). Pendidikan bagi Anak Berkesulitan Belajar. Jakarta: Rineka Cipta.

Lutvaidah, U. (2015). Pengaruh Metode dan Pendekatan Pembelajaran Terhadap Penguasaan Konsep Matematika. Jurnal Formatif, 5 (3), 279-285.

Rusman. (2012). Model-Model Pembelajaran. Jakarta: Raja Grafindo Persada.

Sugiyono. (2015). Metode Penelitian Pendidikan: Pendekatan Kuantitatif, Kualitatif, dan $R$ \& D. Bandung: Alfabeta. 
